\title{
Comparative histochemical study of Bowen's disease and actinic keratosis: preserved normal basal cells in Bowen's disease
}

\author{
H. Ishida ${ }^{1}$, M. Kumakiri ${ }^{1}$, K. Ueda ${ }^{1}$, L.M. Lao ${ }^{1}$, M. Yanagihara ${ }^{2}$, K. Asamoto ${ }^{3}$, Y. Imamura ${ }^{4}$, \\ S. Noriki ${ }^{4}$, and M. Fukuda ${ }^{4}$
}

Departments of ${ }^{1}$ Dermatology, ${ }^{3}$ Anatomy and ${ }^{4}$ Pathology, Fukui Medical University, Matsuoka, Yoshida-Gun, 910 1193 Fukui, Japan and Departments of ${ }^{2}$ Dermatology, Kanazawa Medical University, Uchinada, Kahoku-Gun, 920 0293 Ishikawa, Japan

Accepted: 2/12/00

Key words: immunohistochemistry, in situ hybridisation, AgNOR, DNA instability, Bowen's disease, actinic keratosis

\section{SUMMARY}

The degree of DNA-instability as revealed by immunohistochemical staining with anti-cytidine antibody after acid hydrolysis (DNA-instability test) has been recently used as a marker of malignancy. This technique was applied to examine 17 skin tissue samples of Bowen's disease, 47 of actinic keratosis, 15 of squamous cell carcinoma, 5 of seborrheic keratosis, and 10 of normal skin. All benign neoplastic cells of seborrheic keratosis and normal epidermal cells were negative. On the other hand, all cancer cells were positive with the DNA-instability test, indicating their malignancy, but all basal cells in Bowen's disease were completely negative. Compatible with this result, the basal cells in Bowen's disease were characteristically normal as evident in other histochemical examinations. Thus, they were negative with p53 immunohistochemistry, with normal signals of chromosome 17 in situ hybridisation and argyrophilic nucleolar organiser region, and showed slightly enhanced proliferative activity as revealed by proliferating cell nuclear antigen immunohistochemistry. Immunohistochemical staining with 34 B E12 (monoclonal antibody against cytokeratins
$1,5,10$, and 14), which stains all normal epidermal keratinocytes including basal cells, showed that only the basal cells of Bowen's disease stained strongly and homogeneously, while all cancer cells in the upper layers of Bowen's disease and all layers of actinic keratosis were only sporadically or weakly stained. Staining with 34 B B4 (monoclonal antibody against cytokeratin 1), which recognises the whole epidermis except for the basal layer in the normal epidermis, showed that the basal cells in the Bowen's disease were completely negative, and lower layer cells in the actinic keratosis and upper layer cells in Bowen's disease were only sporadically stained positive, although the superficial layer cells in actinic keratosis stained strongly and homogeneously. Our findings clearly indicate that the basal cells in Bowen's disease are normal. In support of this conclusion, the same cells showed normal morphology on electron microscopy with preserved basement membrane, although the latter was often damaged in actinic keratosis. 


\section{INTRODUCTION}

Both Bowen's disease and actinic keratosis are intraepidermal squamous cell carcinomas with potential progression to invasive squamous cell carcinoma (Sober and Burstein, 1995; Kirkham, 1997; Mackie, 1998). The percentage of cases with Bowen's disease and actinic keratosis that progress to invasive squamous cell carcinoma are 4 (Thestrup-Pedersen et al., 1988) to 5\% (Graham and Helwig, 1973), and 8\% (Glogau, 2000), respectively.

Bowen's disease occurs mainly in sun-exposed skin areas (Thestrup-Pedersen et al., 1988; Kossard and Rosen, 1992) and is possibly caused by ultraviolet light (UV) (Reizner et al., 1994; Chuang et al., 1995), or on the lower extremities (Cox, 1994). A number of studies have demonstrated a relatively high incidence of human papilloma virus (HPV) in Bowen's disease affecting the genital region (38$80 \%$ ) and other skin regions (19.4-40\%), by using Southern blot analysis with HPV 16 DNA (Ikenberg et al., 1983), immunohistochemical staining with viral antigens (Grussendorf-Conen and Giesen, 1990), and in situ hybridisation (ISH) (Kettler et al., 1990). Bowen's disease is also an important complication of chronic hyperarsenism (Yeh et al., 1968; Miki et al., 1982). Histologically, highly atypical cancer cells with clumping lie in complete disorder throughout the epidermis (Kirkham, 1997).

On the other hand, actinic keratosis manifests as hyperkeratotic lesions in sun-exposed adult skin (Mackie, 1998), and the incidence of the disease has been increasing lately (Suzuki et al., 1996). Five types of actinic keratosis have been described; hypertrophic, atrophic, bowenoid, acantholytic, and pigmented, based on histopathological examination. Transition and combination of these types are also known to occur (Kirkham, 1997). Histologically, the intraepidermal units of eccrine ducts and hair canals are spared from the cancer lesion (Hashimoto and Mehregan, 1990), and normal skin grows over the lesion at the borders forming the slanted lines of demarcation (Pinkus, 1958). Bowen's disease and bowenoid type actinic keratosis are histologically identical, except for the accompanying actinic elastosis in the latter, but they are indistinguishable when the former occurs on the sun-exposed skin areas (Hashimoto and Mehregan, 1990; Kirkham, 1997).

The basal layer in Bowen's disease may, however, appear free of dysplasia, in contrast to that of actinic keratosis (Hashimoto and Mehregan, 1990; Lee and Wick, 1990). Basal and suprabasal cells in Bowen's disease also appear almost normal on electron microscopy, except that the tonofilaments in these cells slightly aggregate in a fascicular form (Seiji and Mizuno, 1969). Immunohistochemically, the basal cells are either weakly positive or completely negative for the expression of proliferating cell nuclear antigen (PCNA) (Geary and Cooper, 1992; Takata and Matsui, 1994; Li and Lee, 1996), although the PCNA index (percentage of PCNA-positive cells) is generally high in Bowen's disease (Tsuji et al., 1992).

In the present study, we investigated whether the basal cells in Bowen's disease were normal, and determined the differences in biological characteristics between Bowen's disease and actinic keratosis.

Several histochemical and immunohistochemical techniques have been so far applied to skin cancers. The number of AgNOR (argyrophilic nucleolar organiser region)-signals/nucleus is higher in malignant tumours than in their benign counterparts (Crocker and Skilbeck, 1987; Mackie et al., 1989; Yu et al., 1992). Kanitakis et al. (1992) reported the presence of significantly higher AgNOR count in squamous cell carcinoma (SCC) compared with keratoacanthoma. Onodera et al. (1996) found the highest mean number of AgNOR in SCC lesions, followed in order by Bowen's disease, basal cell carcinoma, actinic keratosis, and seborrheic keratosis. Using interphase cytogenetics, the mean number of signals of chromosome 1 and 17 was significantly higher in malignant melanomas than in other melanocytic neoplasms (De Wit et al., 1994; Matsuta et al., 1994). Hatchoh et al. (1992) demonstrated numerical abnormalities of chromosome 7 in SCC. By using flow cytometry, high aneuploidy rates were detected in both Bowen's disease (9095\%) and actinic keratosis (40-69\%) (Newton et al., 1987; Biesterfeld et al., 1995). P53 immunoreactivity was observed in malignant skin tumours including Bowen's disease and actinic keratosis, but not in seborrheic keratosis and benign melanocytic tumours (McGregor et al., 1992; Ro et al., 1993). Furthermore, UV-specific double-base changes and mutations at dipyrimidine sites were found in the p53 gene of SCC (Brash et al., 1991; Ziegler et al., 1994), and overexpression of p53 protein was demonstrated in Bowen's disease induced by chronic arsenic exposure (Kuo et al., 1997; Hsu et al., 1999). 
Thus, the above methods have demonstrated abnormal gene expression, protein synthesis, disturbed cytodifferentiation, and stimulated proliferative activity of cancer cells reflecting biological changes. However, these methods cannot be used as consistent and specific markers for distinguishing cancer cells from normal cells because the abnormalities found by these methods were only statistically significant. On the other hand, Fukuda et al. $(1986,1993)$ indicated that nuclear DNA of cancer cells is without exceptions always more unstable compared to that of normal and benign tumour cells, irrespective of epithelial or mesenchymal origin. They also developed the method of differential fluorescent or immunohistochemical staining of cancer cells after denaturation of DNA by acid hydrolysis.

In the present study, we used this feature of DNAinstability of cancer cells to identify normal cells remaining in the basal layer of Bowen's disease, together with other histochemical and immunohistochemical methods to characterise the biological characteristics of cancer cells.

\section{MATERIALS AND METHODS}

Immunohistochemical staining of paraffinembedded sections with polyclonal anti-singlestranded DNA antibody after acid hydrolysis to demonstrate DNA-instability (DNA-instability test)

\section{(A) Materials}

Skin biopsies or surgically resected skin specimens were obtained from 17 patients with Bowen's disease, 47 patients with actinic keratosis (hypertrophic type, 17; atrophic type, 18; acantholytic type, 10; bowenoid type, 2), 15 patients with squamous cell carcinoma, 5 patients with seborrheic keratosis, and 10 subjects with normal skin. The specimens were fixed in $10 \%$ buffered formalin for 24 hours at room temperature. Sections were then embedded in paraffin then cut into 4- $\mu \mathrm{m}$ thick sections, deparaffinized with xylene and replaced by ethanol.

\section{(B) Preblocking}

After washing in water, intrinsic peroxidase was blocked with $0.3 \% \quad \mathrm{H}_{2} \mathrm{O}_{2}$ solution dissolved in absolute methanol at $20^{\circ} \mathrm{C}$ for 15 minutes and rinsed with $\mathrm{PBS}$ at $\mathrm{pH}$ 7.4. Sections were treated with $2 \%$ skim-milk (Yukijirushi, Sapporo, Japan) dissolved in PBS ( $\mathrm{pH} \mathrm{7.4)}$ ) at $37^{\circ} \mathrm{C}$ for $20 \mathrm{~min}$ to block the background adsorption of antiserum.

(C) HCl hydrolysis and immunohistochemical staining of single-stranded DNA by the ABC method

Sections were then washed in water, and acid hydrolysis with $2 \mathrm{~N} \mathrm{HCl}$ at $30^{\circ} \mathrm{C}$ was performed for $20 \mathrm{~min}$. Sections were washed in water, again then reacted with the blocking solution (Histofine, Nichirei Corp., Tokyo, Japan). They were reacted with polyclonal antibody to cytidine (Biogenesis, $\mathrm{UK}, 1: 1500$ dilution) at $4^{\circ} \mathrm{C}$ overnight and rinsed with PBS (pH 7.4). Negative controls were provided by omission of the primary antibodies. Sections were reacted with biotinylated goat anti-rabbit IgG (Histofine, Nichirei) at $37^{\circ} \mathrm{C}$ for $40 \mathrm{~min}$, and rinsed with PBS (pH 7.4) and allowed to react with the avidin-biotin peroxidase complex (Histofine, Nichirei) at $37^{\circ} \mathrm{C}$ for $30 \mathrm{~min}$ and then rinsed with PBS pH 7.4.

\section{(D) Co-DAB reaction}

In order to visualise the peroxidase colour reaction, sections were incubated with $\mathrm{DAB}\left(3,3^{\prime}\right.$ diaminobenzidine tetrahydrochloride)-cobalt solution (DAB, Lot. CK114, Dogin, Kumamoto, Japan, $50 \mathrm{mg}$ dissolved in $100 \mathrm{ml}$ of $0.05 \mathrm{M}$ Tris- $\mathrm{HCl}$ buffer $\mathrm{pH} 7.4$, added with $2 \mathrm{ml}$ of $1 \% \mathrm{CoCl}_{2}$ and 10 ul of $30 \% \mathrm{H}_{2} \mathrm{O}_{2}$ solution) at $20^{\circ} \mathrm{C}$ for $10 \mathrm{~min}$ and washed in water. Nuclear counterstaining was carried out with Kernechtrot (Kernechtrot, Chroma, Stuttgart, Germany, $0.1 \mathrm{~g}$ and $5 \mathrm{~g}$ aluminium sulphate dissolved in $100 \mathrm{ml}$ distilled water). The slides were dehydrated through graded alcohol solutions followed by xylene, and mounted.

\section{Immunohistochemical staining for PCNA, p53, and cytokeratins}

\section{(A) Staining methods}

Serial $4 \mu \mathrm{m}$ thick sections were prepared from the same specimens used for the DNA-instability test as described above. After washing with water, intrinsic peroxidase was blocked with $0.3 \% \mathrm{H}_{2} \mathrm{O}_{2}$ solution dissolved in absolute methanol at $20^{\circ} \mathrm{C}$ for 15 min and washed with PBS (pH 7.4). They were digested with $0.1 \%$ trypsin solution $(\mathrm{pH} 7.2)$ (Sigma, St. Louis, MO, USA) at $37^{\circ} \mathrm{C}$ for 15 min only for cytokeratin. All sections including those for 
cytokeratins were irradiated twice in a poly-propylene slide holder with a cap filled with PBS (pH 7.4), over a period of $5 \mathrm{~min}$, using a microwave oven (500 W, ER-245, Toshiba, Tokyo). Sections were then treated with $2 \%$ skim-milk (Yukijirushi, Sapporo, Japan) dissolved in PBS (pH 7.4) at $37^{\circ} \mathrm{C}$ for 20 min to block the background adsorption of the antiserum. They were further reacted with the blocking solution (LSAB Kit, Lot.00046, Dako, Carpinteria, CA, USA) at $20^{\circ} \mathrm{C}$ for $5 \mathrm{~min}$. This was followed by reaction with the following primary antibodies, respectively, at $4^{\circ} \mathrm{C}$ overnight: monoclonal anti-PCNA antiserum (PC-10, NC-012, Lot. 511, Novocastra Laboratories, Newcastle, UK, 1:50 dilution), monoclonal anti-p53 antiserum (DO-1, Lot. 48920216, Oncogene Research Products, USA, 1:40 dilution), monoclonal anti-cytokeratin antiserum (34 B E12, Lot. 044C, Dako, Carpinteria, CA, USA, 1:40 dilution), monoclonal anti-cytokeratin antiserum (34 $\beta$ B4, Lot 10GDA6, Enzo Diagnostics, NY, USA, 1:40 dilution). Negative controls were provided by omission of the primary antibodies. Then the sections were washed with PBS ( $\mathrm{pH}$ 7.4), and further reacted with biotinylated anti-mouse $\operatorname{IgG}$ (LSAB Kit) at $37^{\circ} \mathrm{C}$ for $30 \mathrm{~min}$, followed by rinsing with $\mathrm{PBS}$ (pH 7.4). They were allowed to react with the avidin-biotinperoxidase complex (LSAB Kit) at $37^{\circ} \mathrm{C}$ for 30 min and rinsed with PBS ( $\mathrm{pH} 7.4)$. In order to visualise the peroxidase colour reaction, section were incubated with DAB solution $(20 \mathrm{mg}$ dissolved in $100 \mathrm{ml}$ of $0.05 \mathrm{M}$ Tris- $\mathrm{HCl}$ buffer [pH 7.4]) at $20^{\circ} \mathrm{C}$ for $10 \mathrm{~min}$ and washed in water. Nuclear counterstaining was performed with hematoxylin. The slides were dehydrated by an alcohol series followed by xylene, and mounted.

\section{(B) Evaluation of immunoreactivity}

As per p53 staining, tissue samples containing > $10 \%$ of positively stained cells were regarded as positive. The extent of PCNA-positivity was evaluated by determining the positively stained nuclei in at least 500 epithelial cells in each specimen using an Olympus microscope ( $\times 40$ objective and $\times 10$ eye piece).

\section{AgNOR}

\section{(A) Staining method}

Specimens taken from the same tissues used in other experiments were used for AgNOR staining.
Deparaffinized and alcohol treated specimens were washed in de-ionised and distilled water, and coated with $2 \%$ gelatin dissolved in $0.001 \%$ formic acid solution added with twice the volume of $50 \%$ silver nitrate, and allowed to react at $20^{\circ} \mathrm{C}$ for 20 min under a safety light (No. LA. Kodak, NY, USA). The specimens were then fixed with Fuji-fix solution (Fujifix, Fuji Photo Film, Tokyo, Japan, $445 \mathrm{~g}$ dissolved in 2,000 $\mathrm{ml}$ of de-ionised and distilled water) for $1 \mathrm{~min}$ at room temperature and thoroughly washed in de-ionised and distilled water. No nuclear counterstaining was performed. The slides were dehydrated through an alcohol series followed by xylene, and mounted.

(B) Quantitative analysis of the number, largest size, and maximum shape irregularity of $A g N O R$

The colour image analyser MacScope version 2.56 (Mitani Corporation, Japan) was used for analysis. The image of an optical field of a specimen stained by the AgNOR technique was made by using the objective lens $(\times 100)$. The total number of AgNOR contained in one optical field or in each nucleus was counted manually in the image shown on the cathode ray tube (CRT). Three to five optical fields, namely about 100 cells, were examined in each specimen. The mean value of the maximum shape irregularity of AgNOR expressed as the degree of deviation from a regular circle was determined automatically for the most irregularly-shaped AgNOR in 10 nuclei for each specimen, by the same analyser, on the photograph printed from the image viewed on the CRT with a final magnification of $\times 1,000$.

\section{In situ hybridisation}

\section{(A) Processing of paraffin sections}

$4 \mu \mathrm{m}$ paraffin sections were cut from the same tissues used in other experiments and floated in warm $\left(40^{\circ} \mathrm{C}\right)$ water followed by mounting on silanised slides (DAKO). The slides were air dried overnight at $40^{\circ} \mathrm{C}$, dewaxed in xylene and rehydrated through a decreasing alcohol series to water. The slides were then immersed in methanol supplemented with $0.3 \% \mathrm{H}_{2} \mathrm{O}_{2}$ for 15 min to block endogenous peroxidase activity. After washing with distilled water and rinsing in PBS ( $\mathrm{pH} 7.4)$, they were digested with $0.25 \%$ trypsin solution (Sigma) at $37^{\circ} \mathrm{C}$ for 20 to $60 \mathrm{~min}$. The slides were 
finally washed with PBS twice for 5 min, rinsed in distilled water, and processed for ISH.

\section{(B) In situ hybridisation}

The probe used in this study was a biotin labelled $\alpha$-satellite DNA probe specific for the pericentrometric region of chromosome 17 (D17Z1, Lot. 5C219, Oncor, Gaithersburg, MD, USA). A hybridisation mixture was prepared which consisted of $50 \%$ formamide, $20 \%$ dextran sulphate, $2 \times \mathrm{SSC}(0.3 \mathrm{M}$ $\mathrm{NaCl}, 0.03 \mathrm{M}$ sodium citrate and $0.04 \mathrm{M}$ disodium hydrogen phosphate, $\mathrm{pH}$ 6.0), $10 \mu \mathrm{g} / \mathrm{ml}$ carrier salmon testes DNA (Lot. M9E4924, Nacalai tesque, Kyoto, Japan), 1/50 Denhardt's solution, and biotinlabelled probe $(10 \mu \mathrm{l} / \mathrm{ml}$ of the hybridisation solution). The mixture was denatured at $73^{\circ} \mathrm{C}$ for $10 \mathrm{~min}$ and rapidly cooled on ice. The slides were denatured by immersion in a solution containing $70 \%$ formamide in $2 \times \mathrm{SSC}$ at $73^{\circ} \mathrm{C}$ for $10 \mathrm{~min}$ and rapidly cooled by rinsing in $70 \%$ cold ethanol (prechilled at $-20^{\circ} \mathrm{C}$ for $5 \mathrm{~min}$ ), followed by sequential dehydration in $70 \%, 80 \%, 90 \%$, and $100 \%$ ethanol at room temperature. The slides were air dried and incubated with the hybridisation mixture, and covered with a cover slip. Hybridisation was carried out at $37^{\circ} \mathrm{C}$ in a moist chamber containing $50 \%$ formamide and $2 \times$ SSC for 48 hours. Following hybridisation, the slides were immersed in $2 \times$ SSC to remove the cover slips. Post hybridisation washing was done in $50 \%$ formamide in $2 \times \mathrm{SSC}$ at $41^{\circ} \mathrm{C}$ for $10 \mathrm{~min}, 30 \%$ formamide in $2 \times \mathrm{SSC}$ at $37^{\circ} \mathrm{C}$ for $8 \mathrm{~min}$, and $1 \times$ $\mathrm{SSC}$ at room temperature for $5 \mathrm{~min}$. The slides were then rinsed in distilled water and dehydrated through increasing concentrations of ethanol. The bound probe was visualised by air drying the slides at room temperature followed by the conventional $\mathrm{ABC}$ method of immunodetection using DAB as chromogen and $\mathrm{H}_{2} \mathrm{O}_{2}$ as substrate. The slides were counterstained with hematoxylin, dehydrated through an alcohol series followed by xylene and were finally mounted.

\section{(C) Scoring of interphase nuclei}

After hybridisation, at least 200 nuclei were counted from each section using a conventional light microscope with an oil immersion lens $(x$ 100). In all specimens, signal in stromal cells and lymphocytes served as an internal control. In each section, counts of cells showing nil, 1, 2, 3, 4, 5, or more hybridised signals were determined and the percentage of hyperdiploid cells (3 or more signals within 1 nucleus) was determined in each specimen.

\section{Electron microscopy}

For routine electron microscopic observation, tissues were fixed in $2.5 \%$ glutaraldehyde buffered with PBS ( $\mathrm{pH} \mathrm{7.4)}$ at $4^{\circ} \mathrm{C}$ and postfixed in $1 \%$ osmium tetroxide in the same buffer for 1 hour. After dehydration in a series of graded concentrations of alcohol, the tissues were embedded in Epon 812. The $1 \mu \mathrm{m}$ semi-thin sections were stained with toluidine blue to select appropriate areas for study. Ultrathin sections were cut by an ultratome (Ultracut N, Reichert-Nissei) with a diamond knife, doubly stained with uranyl acetate and lead citrate, and examined and photographed under an electron microscope (H-600, Hitachi, Tokyo, Japan) at an accelerating voltage of $75 \mathrm{kV}$.

\section{Reticulin silver impregnation}

$4 \mu \mathrm{m}$ paraffin sections were cut from the same tissues used in other experiments and dewaxed in xylene and rehydrated through a decreasing alcohol series to water. The slides were immersed in $0.25 \%$ potassium permanganate for $10 \mathrm{~min}$. After washing with distilled water, they were immersed in $2 \%$ oxalic acid for 2 min, washed with distilled water, then immersed in $2 \%$ ferric ammonium sulphate for $50 \mathrm{sec}$. After washing with water, they were rinsed in three changes of distilled water for 2 min each and immersed for 15 min in a solution prepared by adding in order: $10 \mathrm{ml}$ of $10 \%$ silver nitrate, $5 \mathrm{ml}$ of $4 \%$ potassium hydroxide, a small quantity of $28 \%$ ammonia solution, $185 \mathrm{ml}$ of distilled water. Then they were rinsed briefly in $95 \%$ ethyl alcohol and immersed successively in 120 $\mathrm{ml}$ of $1 \%$ formalin added with $2 \mathrm{ml}$ of $2 \%$ ferric ammonium sulphate for $3 \mathrm{~min}$. After washing with distilled water, they were immersed in $1 \%$ gold chloride for $10 \mathrm{~min}$ or longer. After washing with distilled water, they were immersed in $2 \%$ oxalic acid for $20 \mathrm{sec}$. After washing with water, they were then fixed with Fuji-fix solution (Fujifix, Fuji Photo Film, Tokyo, Japan, $445 \mathrm{~g}$ dissolved in 2,000 $\mathrm{ml}$ of de-ionised and distilled water) for 1 min, thoroughly washed in distilled water, dehydrated through an alcohol series followed by xylene and were finally mounted. 


\section{Statistical Analysis}

PCNA-index, AgNOR parameters, and ISH data are expressed as mean \pm standard deviation (SD). Differences between groups were examined for statistical significance using the Student's $t$ - test. A $P$ value less than 0.05 denoted the presence of a statistically significant difference.

\section{RESULTS}

The results of the DNA-instability test, immunohistochemical staining of PCNA, p53, quantitative analysis of AgNOR-parameters and chromosome 17 ISH are summarised in Tables I and II. The negative controls for all immunohistochemical stainings including the DNA-instability test gave completely negative staining.

\section{DNA-instability test}

The DNA-instability test was positive in SCC (Fig. 1a), and negative in seborrheic keratosis (Fig. 1b); virtually all neoplastic cells were positively stained in positive cases and negatively stained in negative cases. All layers in hypertrophic, atrophic, and acantholytic type actinic keratosis, and all layers except for basal layer in bowenoid type actinic keratosis and in Bowen's disease showed positivity indicating increased DNA-instability comparable to that of malignant tumours (Fig. 1c, d). The basal cells in bowenoid type actinic keratosis and in Bowen's disease, and normal epidermal cells were completely negative (Fig. 1d).

\section{PCNA immunohistochemistry}

PCNA indices were significantly higher in upper layer cells in Bowen's disease, SCC, and actinic keratosis than those of basal cells in Bowen's disease, normal skin, and seborrheic keratosis. Moreover, PCNA indices of the upper layers in Bowen's disease and in bowenoid type actinic keratosis were statistically higher than those of hypertrophic, atrophic, and acantholytic type actinic keratosis. No difference in PCNA indices were found in the basal layer of Bowen's disease and bowenoid type actinic keratosis, seborrheic keratosis, and normal skin. PCNA labelled cells were mainly recognised at the periphery of the nests in SCC (Fig. 1e), in the lower layers in hypertrophic, atrophic, and acantholytic type actinic keratosis
(Fig. 1f), and in the whole epidermis except for the basal layer in Bowen's disease and in bowenoid type actinic keratosis (Fig. 1g, h).

\section{AgNOR parameters}

The values of AgNOR-number were significantly higher in the upper layers in Bowen's disease, actinic keratosis, and SCC (Fig. 1i, j, k) than those in the basal layer in Bowen's disease, seborrheic keratosis and normal skin. In the upper layers of Bowen's disease and bowenoid type actinic keratosis, the values of AgNOR-number were significantly higher than those of hypertrophic, atrophic, and acantholytic type actinic keratosis, but the values of largest size and maximum shape irregularity of AgNOR were significantly lower than those of them (Fig. 1j, k, 1). The values of largest size and maximum shape irregularity in SCC were highest. In AgNOR-parameters, no difference was found in the basal layer in Bowen's disease, in bowenoid type actinic keratosis, and in normal skin.

\section{p53 immunohistochemistry}

Thirty-four cases of actinic keratosis were positive for p53 immunostaining (Fig. 1m), but no difference was found between hypertrophic, atrophic, and acantholytic type actinic keratosis. Eight cases of Bowen's disease and 1 case of bowenoid type actinic keratosis were positive, but the basal cells of these positive cases were negative (Fig. 1n).

\section{Interphase Cytogenetics}

A total of 45 cases from the specimens used in the above experiments were studied by this method. The control normal epidermis showed 0,1 or 2 signals/nucleus. Similarly, stromal cells and lymphocytes also showed 0,1 or 2 signals/nucleus. Cells exhibiting 3 or more chromosome copies/nucleus were recognised in all cases of Bowen's disease, actinic keratosis (Fig. 1o, p), and SCC. The percentage of hyperdiploid cells was significantly higher in actinic keratosis and SCC than in Bowen's disease. No difference was found between hypertrophic, atrophic, and acantholytic type actinic keratosis. No hyperdiploid cells were recognised in basal layer cells in Bowen's disease (Fig. 1p) and seborrheic keratosis. ISH methods in two cases of bowenoid type actinic keratosis were unfortunately unsuccessful. 


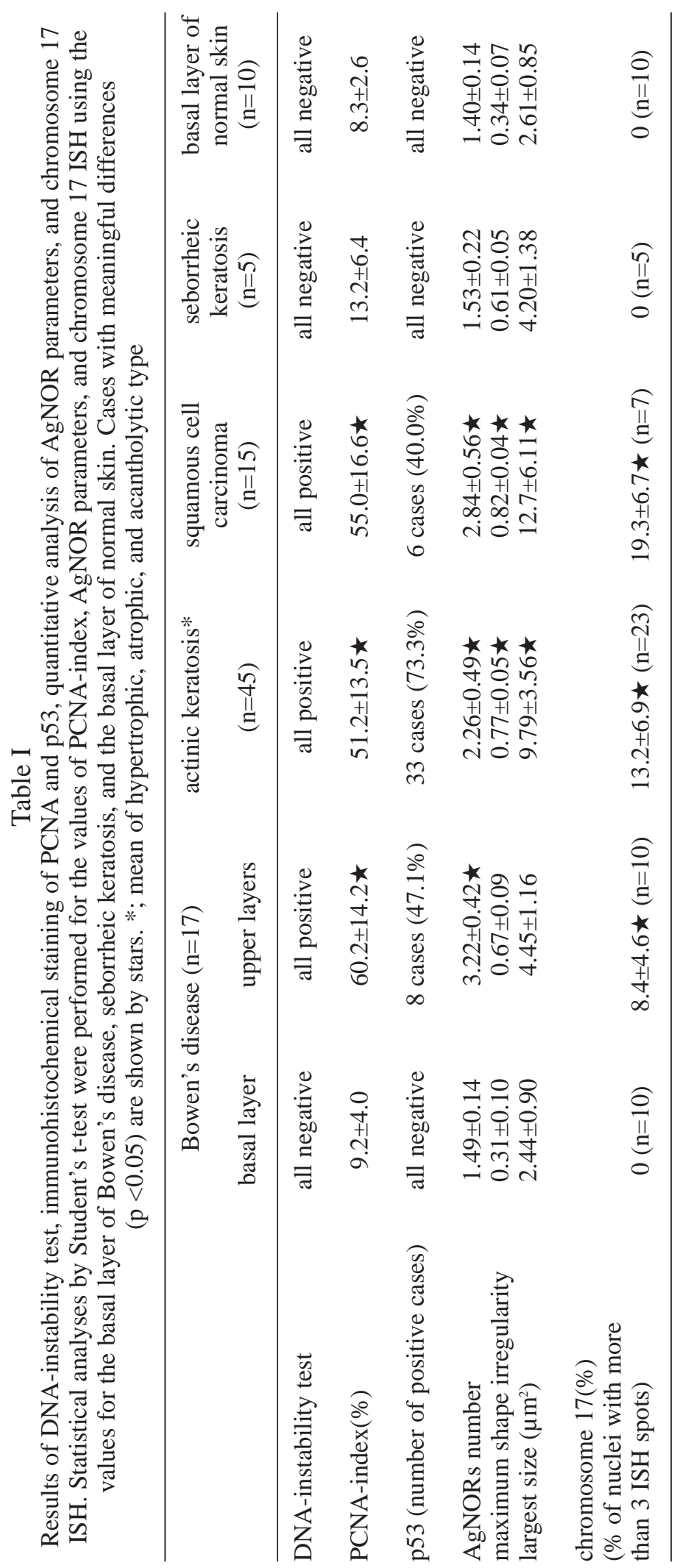

Cytokeratin immunohistochemistry

Immunohistochemical staining with $34 \mathrm{~B}$ E12 (monoclonal antibody against cytokeratins $1,5,10$, and 14), which stains all normal epidermal keratinocytes including basal cells, showed strong and homogeneous staining of the basal cells of Bowen's disease and bowenoid type actinic keratosis. Only sporadic or weak staining was noted in all cancer cells in the upper layers of Bowen's disease and bowenoid type actinic keratosis, and all layers of hypertrophic, atrophic, and acantholytic type actinic keratosis (Fig. 2a, b, c). Immunohistochemical staining with 34 B B4 (monoclonal antibody against cytokeratin 1), which recognises the whole epidermis except for the basal layer in the normal epidermis, showed lack of staining in the basal cells in Bowen's disease and bowenoid type actinic keratosis. Furthermore, only sporadic staining was noted in the lower layer cells in the hypertrophic, atrophic, and acantholytic type actinic keratosis, and upper layer cells in Bowen's disease and bowenoid type actinic keratosis. However, homogeneous and strong staining was noted in the superficial layer cells in hypertrophic, atrophic, and acantholytic type actinic keratosis (Fig. 2d, e, f).

\section{Electron microscopy}

The following ultrastructural changes were observed mainly in the spinous layer in cases of Bowen's disease (Fig. 3a): central displacement and aggregation of condensed tonofilaments; decrease in tonofilamentdesmosomal attachment; multinucleated giant cells; and abnormal mitosis. The basal cells in Bowen's disease generally exhibited normal appearance, which were characterised by normal polarity, normal cytoplasmic features such as tonofibrils, lipid droplets and mitochondria (Fig. 3a). They were connected to the neighbouring healthy cells or tumour cells by normal desmosomes, and fixed on the basement membrane by half-desmosomes with normal appearance and numbers (Fig. 3b). The well-developed basement membrane sharply separated the epidermis from dermis 


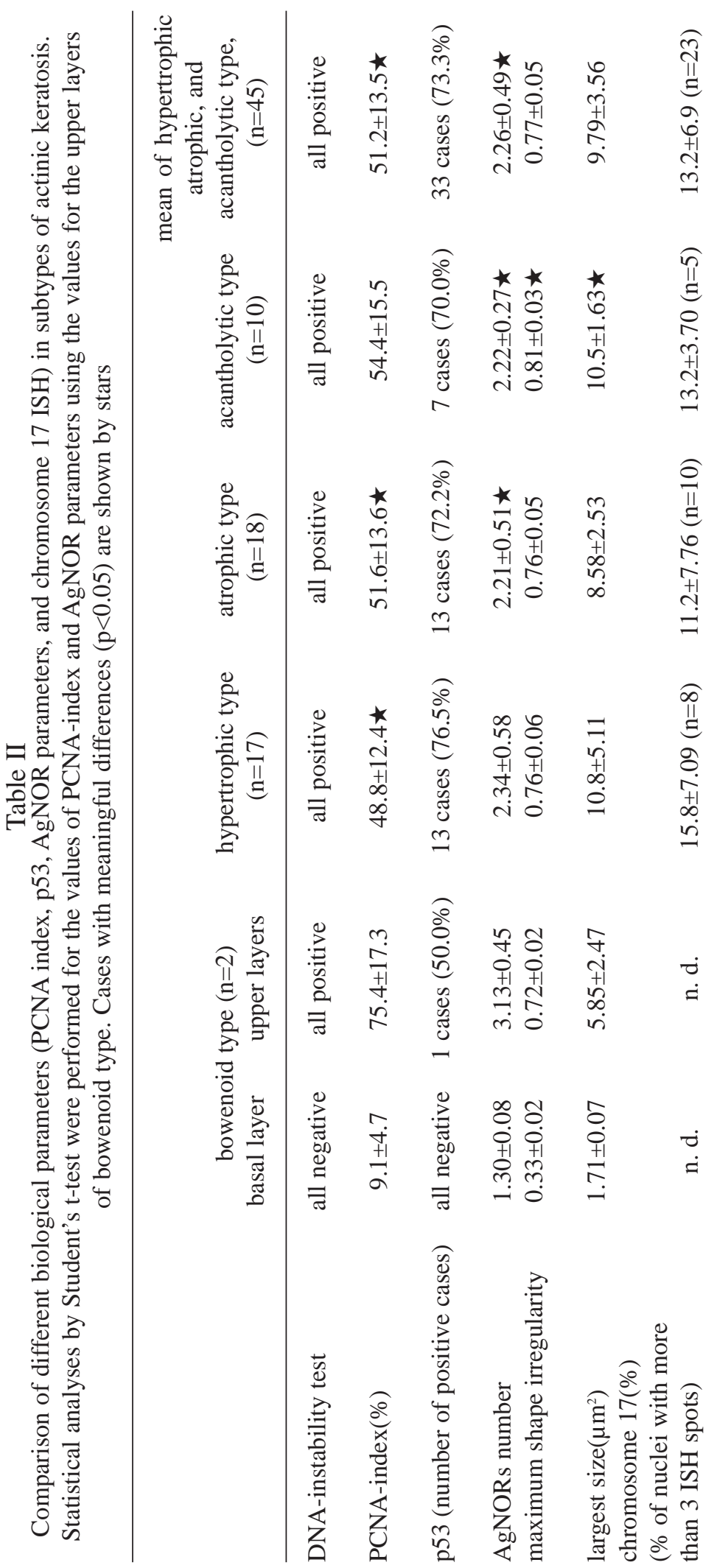

and was intact in all examined tissue specimens (Fig. 3b).

At the dermal-epidermal junction of the lesions in hypertrophic, atrophic, and acantholytic type actinic keratosis, the basement membrane showed sporadic discontinuity and a partial decrease in the number of half-desmosomes, in addition to focal separation from the basal cells (Fig. 3c). The presence of double or multiple basement membranes was often observed. The desmosomes between tumour cells seemed to be normal.

\section{Reticulin silver impregnation}

In Bowen's disease, positivelystained fibres appeared to be continuous without any disruptions at the dermal-epidermal junction (Fig. 4a), but those in hypertrophic, atrophic, and acantholytic type actinic keratosis were often partially disrupted (Fig. 4b).

\section{DISCUSSION}

Fukuda et al. (1986, 1992) reported that DNA-instability is a specific and common marker of malignancy irrespective of epithelial or mesenchymal origin. Based on this finding, they developed the method of differential staining of malignant cells with acridine orange or antisingle-stranded DNA antiserum based on the phenomenon of increased production of denatured single-stranded DNA in cancer cells than in comparable normal cells after acid hydrolysis. Based on the degree of DNA-instability by acid hydrolysis, as revealed in the present study, our results reconfirmed that seborrheic keratosis belongs to the benign category, while SCC, actinic keratosis, and Bowen's disease were found to belong to the malignancy category. 

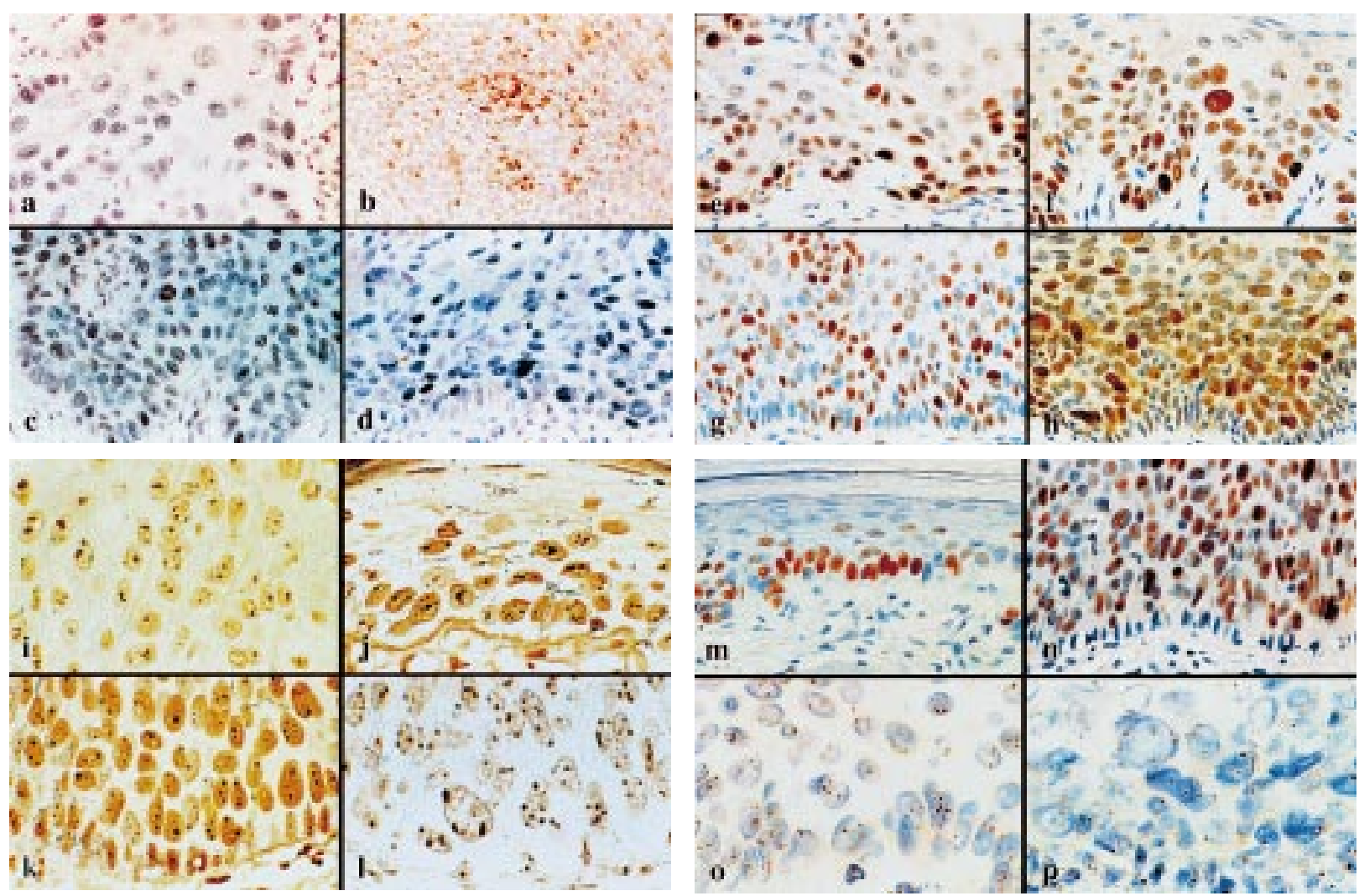

Fig. 1 - Immunohistochemical staining of anti-single stranded DNA antibody (a-d). a: SCC $(\times 132)$, b: seborrheic keratosis $(\times 132)$, c: actinic keratosis $(\times 132)$, d: Bowen's disease $(\times 132)$. Immunohistochemical staining of PCNA (e-h). e: SCC $(\times 100)$, f: actinic keratosis $(\times 132)$, g: Bowen's disease $(\times 132)$, h: bowenoid type actinic keratosis $(\times 132)$. AgNORs staining (i-1). i: SCC $(\times 250)$, j: actinic keratosis $(\times 250)$, k: Bowen's disease $(\times 250)$, l: bowenoid type actinic keratosis $(\times 330)$. Immunohistochemical staining of p53 (m-n). m: actinic keratosis (×132), n: Bowen's disease $(\times 132)$. Chromosome 17 ISH signals (o-p). o: actinic keratosis $(\times 250)$, p: Bowen's disease $(\times 330)$.

Cytokeratins are the major structural proteins of epithelial cells. Monoclonal antibody 34 ß E12 (against cytokeratins 1, 5, 10, and 14) stains all normal epidermal keratinocytes including basal cells (Gown and Vogel, 1982) and squamous cell

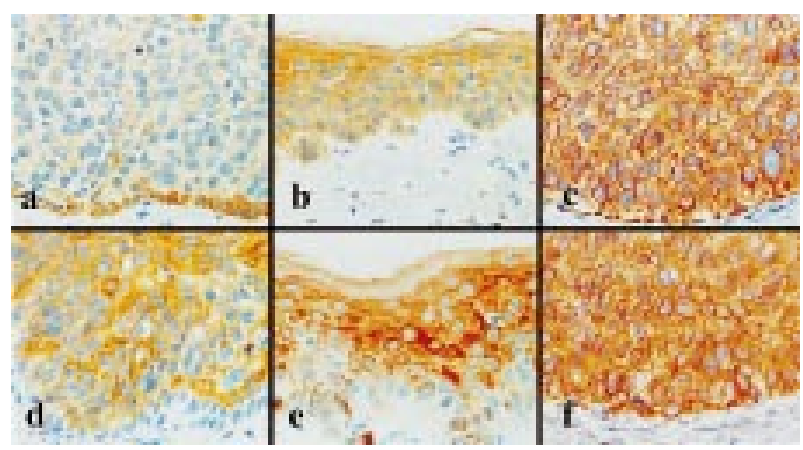

carcinoma (Gown and Vogel, 1985). On the other hand, monoclonal antibody 34 ß B4 (against cytokeratins 1) recognises the whole epidermis except for the basal layer in the normal epidermis (Gown and Vogel, 1984). Immunohistochemical

Fig. 2 - Immunohistochemical staining of cytokeratin $(34 \beta$ E12) (×132) (a-c). a: Bowen's disease, b: actinic keratosis, c: bowenoid type actinic keratosis. Immunohistochemical staining of cytokeratin (34 B B4) (×132) (d-f). d: Bowen's disease, e: actinic keratosis, $\mathbf{f}$ : bowenoid type actinic keratosis. 


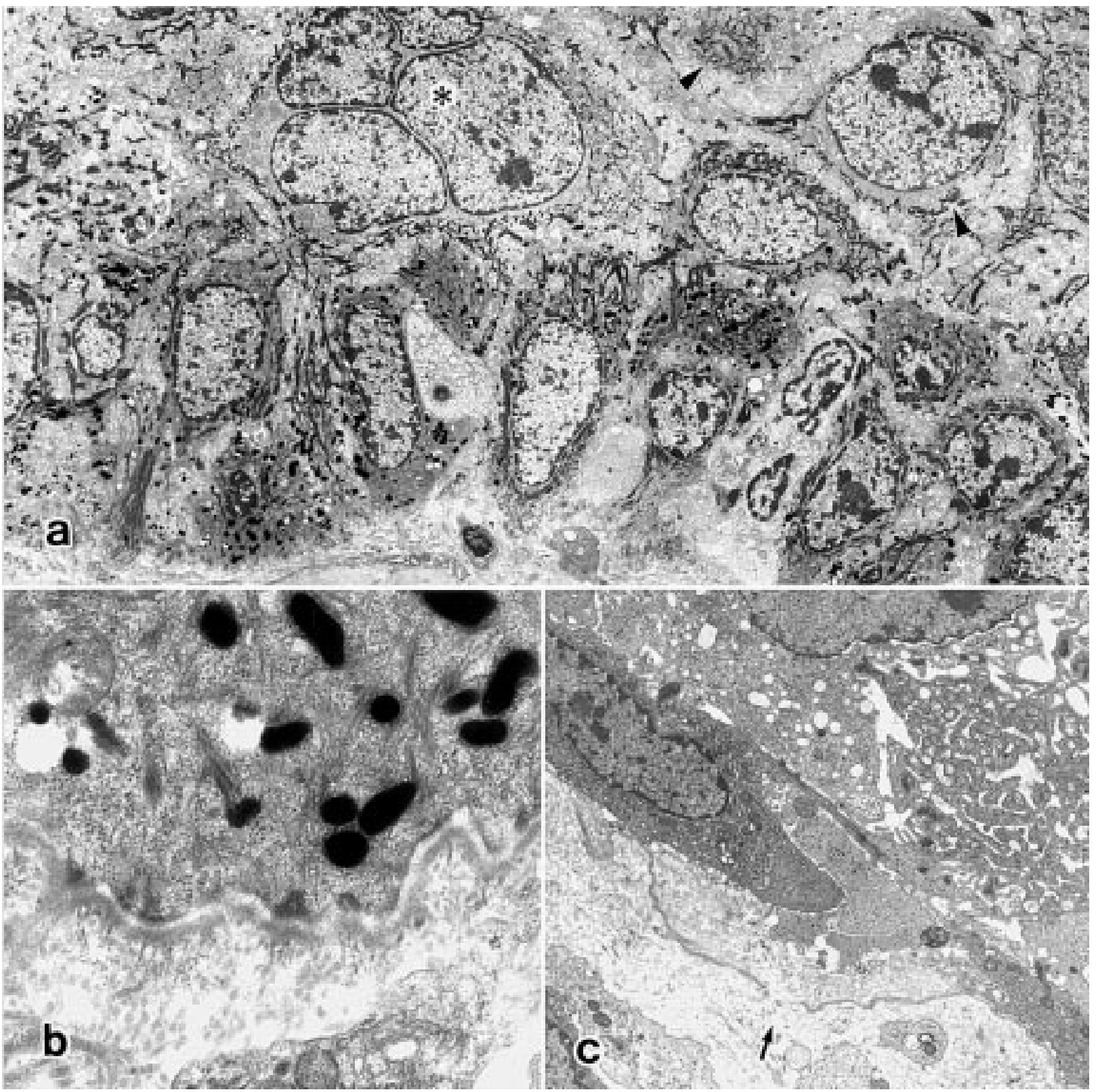

Fig. 3 - Electron microscopy (a-c). a: Electron micrograph of the lower part of the epidermis from a patient with Bowen's disease. Note the multinucleated giant cells $(*)$ and dyskeratotic cells (arrowheads) in the spinous layer. $(\times 2,200)$, b: High magnification of a portion of the basal cell from A. $(\times 25,000)$, c: Basal layer from the lesion of actinic keratosis. The arrow indicates a focal separation of basement membrane from the basal cells. $(\times 6,000)$.

staining of tissue samples of Bowen's disease and actinic keratosis in the present study using these antibodies showed a heterogeneous staining pattern in tumour cells except for the basal layer in Bowen's disease and in bowenoid type actinic keratosis. Specifically, with 34 B E12, these cancer cells showed only sporadic or weak staining. With
34 B B4, the lower layer cells in the hypertrophic, atrophic, and acantholytic type actinic keratosis, and upper layer cells in Bowen's disease and in bowenoid type actinic keratosis showed sporadic staining. However, the superficial layer cells in hypertrophic, atrophic, and acantholytic type actinic keratosis were strongly and homogeneous- 


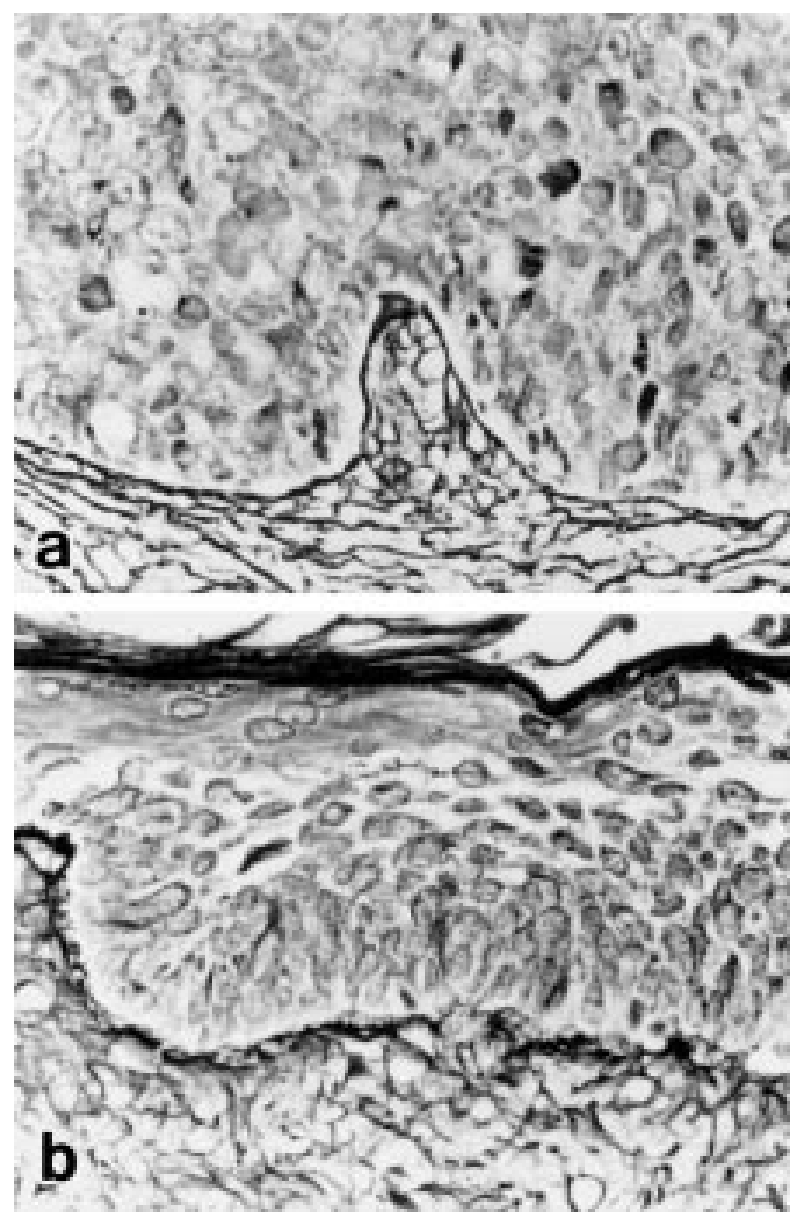

Fig. 4 - Reticulin silver impregnation $(\times 132)$ (a-b). a: Bowen's disease, b: actinic keratosis.

ly stained with 34 B B4. Only the basal cells of Bowen's disease and bowenoid type actinic keratosis showed a staining pattern that was similar to that of the basal cells of normal epidermis; they were strongly and homogeneously stained with 34 B E12 and were completely negative with 34 B B4. The basal layer of Bowen's disease may appear free of dysplasia, in contrast to that of actinic keratosis, on light microscopy (Hashimoto and Mehregan, 1990; Lee and Wick, 1990) and electron microscopy (Seiji and Mizuno, 1969). It is, however, not always easy to characterise this layer as benign based upon simple routinely used morphological criteria, because cellular atypia in malignant tumours is not usually markedly pronounced. The correlation between morphological appearance and biological characteristics may not always be satisfactory and reliable. In the DNA-instability test, all basal cells in Bowen's disease were completely negative. Compatible with this result, the characteristics of basal cells in Bowen's disease were comparable to those of normal basal cells examined by other histochemical techniques; they were negative with p53 immunohistochemistry, showed normal signals of chromosome 17 in ISH and AgNOR, revealed slightly enhanced proliferative activity by PCNA immunohistochemistry, and showed similar staining pattern to the normal basal cells by cytokeratin immunohistochemistry.

All these observations clearly indicate that the basal cells in Bowen's disease are biologically normal. In support of this conclusion, the basement membrane in Bowen's disease appeared normal, in contrast to that in actinic keratosis, which showed sporadic discontinuities by electron microscopy and reticulin silver impregnation stain. It is reasonable to speculate that the presence of a normal basal cell layer is related to the notable infrequency with which Bowen's disease progresses to invasive carcinoma (Graham and Helwig, 1973; Thestrup-Pedersen et al., 1988) and to the frequent recognition of large macules or plaques in Bowen's disease, regardless of the presence of markedly atypical epidermal cells and high growth fraction. On the other hand, atypical cells were distributed both in the basal and suprabasal layers by microscopic and histochemical examinations in hypertrophic, atrophic, and acantholytic type actinic keratosis. Both Bowen's disease and actinic keratosis are thought to arise from basal cells with proliferative activity. In Bowen's disease, however, cancer cells cannot remain in the basal layer for one reason or another and presumably they proliferate first in the spinous layer to take the form of intraepidermal carcinoma, and continue proliferating further to replace normal epidermal cells, leaving only basal cells. The underlying mechanism of such a proliferating pattern in Bowen's disease remains unknown. However, it is speculated that Bowen's disease undergoes changes different from those of actinic keratosis with respect to cell adhesion in the early stage of carcinogenesis, thus making it impossible for cancer cells to remain in the basal layer in the former. Alternatively, it is possible that the proteins that constitute half-desmosomes necessary for adhesion with the basement membrane are abnormal in Bowen's disease. The appearance of intercellular desmosomes was 
almost normal on electron microscopy in Bowen's disease. Previous studies have shown that the expression of E-cadherin, one of the constituent proteins in intercellular adherens junction, does not differ from that of the normal epidermis (Fuller et al., 1996), although a low expression level of desmoglein 1 , one of the constituent proteins of desmosomes, has been reported (Tada et al., 2000). However, there are no reports describing the presence of abnormal constituent proteins of halfdesmosomes. Half-desmosomes in Bowen's disease are the subject of future studies, and Bowen's disease will serve as an interesting material for studying intercellular adhesion.

Actinic keratosis appears to show a tendency to normal differentiation as revealed by cytokeratin staining. On the other hand, Bowen's disease shows an intense nuclear atypia and no tendency for differentiation. Our results revealed that the PCNAindex, a marker of proliferative activity, was higher in Bowen's disease than in actinic keratosis. In actinic keratosis, however, the frequency of abnormality of chromosome 17 was high and mutation of p53 was also noted at high frequency compared with those in Bowen's disease. These findings suggest that actinic keratosis and Bowen's disease differ with respect to carcinogenesis, and that the DNA damage may be more prominent in actinic keratosis than in Bowen's disease. The signals of AgNOR in Bowen's disease, except for the normal basal cells, were small and round although the number was large, while those in actinic keratosis were larger and more irregularly shaped although the number was smaller, like those in invasive squamous cell carcinoma. These results clearly indicate that the malignant potential of actinic keratosis is higher than that of Bowen's disease irrespective of the degree of morphological atypism. Previous studies have suggested that progression of actinic keratosis to invasive squamous cell carcinoma is rather rare (Kirkham, 1997; Mackie, 1998), although more recent studies have reported the incidence to be as high as $8 \%$ (Glogau, 2000).

The staining patterns of bowenoid type actinic keratosis were similar to those of Bowen's disease, indicating that the basal cells of bowenoid type actinic keratosis remained normal. These results suggest that bowenoid type actinic keratosis and Bowen's disease are not biologically different. Therefore, it is possible that bowenoid type actinic keratosis is Bowen's disease that has developed in the part exposed to light.

In conclusion, we have demonstrated in the present study that the basal cells were normal in Bowen's disease and bowenoid type actinic keratosis while those in other types of actinic keratosis were replaced by cancer cells.

\section{REFERENCES}

Biesterfeld S., Pennings K., Grussendorf-Conen E.I., and Bocking A.: Aneuploidy in actinic keratosis and Bowen's disease-increased risk for invasive squamous cell carcinoma? Br. J. Dermatol. 133, 557-560, 1995.

Brash D.E., Rudolph J.A., Simon J.A., Lin A., McKenna G.J., and Baden H.P., Halperin A.J., Ponten J.: A role for sunlight in skin cancer: UV-induced p53 mutations in squamous cell carcinoma. Proc. Natl. Acad. Sci. USA 88, 10124-10128, 1991.

Chuang T.Y., Reizner G.T., Elpern D.J., Stone J.L., and Farmer E.R.: Nonmelanoma skin cancer in Japanese ethnic Hawaiians in Kauai, Hawaii: an incidence report. J. Am. Acad. Dermatol. 33, 422-426, 1995.

Cox N.H.: Body site distribution of Bowen's disease. Br. J. Dermatol. 130, 714-716, 1994.

Crocker J., and Skilbeck N.: Nucleolar organiser region associated proteins in cutaneous melanotic lesions: a quantitative study. J. Clin. Pathol. 40, 885-889, 1987

De Wit P.E., Kerstens H.M., Poddighe P.J., Van Muijen G.N., and Ruiter D.J.: DNA in situ hybridisation as a diagnostic tool in the discrimination of melanoma and Spitz naevus. J. Pathol. 173, 227-233, 1994.

Fukuda M., Miyoshi N., Hattori T., Sugihara H., Hosokawa Y., and Nakanishi K.: Different instability of nuclear DNA at acid hydrolysis in cancer and noncancer cells as revealed by fluorescent staining with acridine orange. Histochemistry 84 , 556-560, 1986

Fukuda M., Noriki S., Imamura Y., Miyoshi N., Kimura S., Koizumi K., Suzuki K., Sakurai H., and Sakaguchi R.: Differential immunohistochemical staining of cancer cells with anti-single-stranded DNA antiserum in ordinary pathological paraffin section after DNA-denaturation by acid hydrolysis. Eur. J. Histochem. 37, 309-319, 1993.

Fuller L.C., Allen M.H., Montesu M., Barker J.N., and Macdonald D.M.: Expression of E-cadherin in human epidermal non-melanoma cutaneous tumours. Br. J. Dermatol. 134, 28 32,1996

Geary W.A., and Cooper P.H.: Proliferating cell nuclear antigen (PCNA) in common epidermal lesions. An immunohistochemical study of proliferating cell populations. J. Cutan. Pathol. 19, 458-468, 1992. 
Glogau R.G.: The risk of progression to invasive disease. J. Am. Acad. Dermatol. 42, 23-24, 2000.

Gown A.M., and Vogel A.M.: Monoclonal antibodies to intermediate filament proteins of human cells: unique and crossreacting antibodies. J. Cell Biol. 95, 414-424, 1982.

Gown A.M., and Vogel A.M.: Monoclonal antibodies to human intermediate filament proteins. II. Distribution of filament proteins in normal human tissues. Am. J. Pathol. 114, 309-321, 1984.

Gown A.M., and Vogel A.M.: Monoclonal antibodies to human intermediate filament proteins. III. Analysis of tumors. Am. J. Clin. Pathol. 84, 413-424, 1985.

Graham J.H., and Helwig E.B.: Erythroplasia of Queyrat. A clinicopathologic and histochemical study. Cancer 32, 13961414, 1973.

Grussendorf-Conen E.I., and Giesen M.: Papillomavirus common antigen in Bowen's disease. Dermatologica 181, 11-15, 1990.

Hashimoto K., and Mehregan A.H.: Tumors of the epidermis, Butterworth, Stoneham, 1990.

Hatchoh M., Ueda K., Imamura Y., Noriki S., and Fukuda M.: Qualitative and quantitative changes in nuclear DNA and phenotypic gene expression in human malignant skin tumors during their progression. Eur. J. Histochem. 36, 289-302, 1992.

Hsu C.H., Yang S.A., Wang J.Y., Yu H.S., and Lin S.R.: Mutational spectrum of p53 gene in arsenic-related skin cancers from the blackfoot disease endemic area of Taiwan. Br. J. Cancer 80, 1080-1086, 1999.

Ikenberg H., Gissmann L., Gross G., Grussendorf-Conen E.I., and zur Hausen H.: Human papillomavirus type-16-related DNA in genital Bowen's disease and in Bowenoid papulosis. Int. J. Cancer 32, 563-565, 1983.

Kanitakis J., Hoyo E., Hermier C., Chouvet B., and Thivolet J.: Nucleolar organizer region enumeration in keratoacanthomas and squamous cell carcinomas of the skin. Cancer 69 , 2937-2941, 1992.

Kettler A.H., Rutledge M., Tschen J.A., and Buffone G.: Detection of human papillomavirus in nongenital Bowen's disease by in situ DNA hybridisation. Arch. Dermatol. 126, 777-781, 1990.

Kirkham N.: Tumors and cysts of the epidermis In: Lever's histopathology of the skin, 8th edn. (Eds. Elder D., Elenitsas R., Jaworsky C., and Johnson B.), Lippincott-Raven, Philadelphia, pp. 685-746, 1997.

Kossard S., and Rosen R.: Cutaneous Bowen's disease. An analysis of 1001 cases according to age, sex, and site. J. Am. Acad. Dermatol. 27, 406-410, 1992.

Kuo T.T., Hu S., Lo S.K., and Chan H.L.: p53 expression and proliferative activity in Bowen's disease with or without chronic arsenic exposure. Hum. Pathol. 28, 786-790, 1997.

Lee M.M., and Wick M.M.: Bowen's disease. C.A. Cancer J. Clin. 40, 237-242, 1990.
Li J., and Lee Y.S.: Proliferating cell nuclear antigen (PCNA) expression in pseudoepitheliomatous hyperplasia, keratoacanthoma and squamous cell carcinoma of the skin. Ann. Acad. Med. Singapore 25, 526-530, 1996.

Mackie R.M., White S.I., Seywright M.M., and Young H.: An assessment of the value of Ag NOR staining in the identification of dysplastic and other borderline melanocytic naevi. $\mathrm{Br}$. J. Dermatol. 120, 511-516, 1989.

Mackie R.M.: Epidermal skin tumours. In: Rook/Wilkinson/Ebling textbook of dermatology, 6th edn. (Eds. Champion R.H., Burton J.L., Burns D.A., and Breathnach S.M.) Blackwell Science, Oxford, pp. 1651-1693, 1998.

Matsuta M., Matsuta M., Kon S., Thompson C., LeBoit P.E., Weier H.U., and Gray J.W.: Interphase cytogenetics of melanocytic neoplasms: numerical aberrations of chromosomes can be detected in interphase nuclei using centromeric DNA probes. J. Cutan. Pathol. 21, 1-6, 1994.

McGregor J.M., Yu C.C., Dublin E.A., Levison D.A., and MacDonald D.M.: Aberrant expression of p53 tumour-suppressor protein in non-melanoma skin cancer. Br. J. Dermatol. 127, 463-469, 1992.

Miki Y., Kawatsu T., Matsuda K., Machino H., and Kubo K.: Cutaneous and pulmonary cancers associated with Bowen's disease. J. Am. Acad. Dermatol. 6, 26-31, 1982.

Newton J.A., Camplejohn R.S., and McGibbon D.H.: A flow cytometric study of the significance of DNA aneuploidy in cutaneous lesions. Br. J. Dermatol. 117, 169-174, 1987.

Onodera H., Nakamura S., and Sugai T.: Cell proliferation and p53 protein expressions in cutaneous epithelial neoplasms. Am. J. Dermatopathol. 18, 580-588, 1996.

Pinkus H.: Keratosis senilis: a biologic concept of its pathogenesis and diagnosis based on the study of normal epidermis and 1730 seborrheic and senile keratoses. Am. J. Clin. Pathol. 29, 193-207, 1958.

Reizner G.T., Chuang T.Y., Elpern D.J., Stone J.L., and Farmer E.R.: Bowen's disease (squamous cell carcinoma in situ) in Kauai, Hawaii. A population-based incidence report. J. Am. Acad. Dermatol. 31, 596-600, 1994.

Ro Y.S., Cooper P.N., Lee J.A., Quinn A.G., Harrison D., Lane D., Horne C.H., Rees J.L., and Angus B.: p53 protein expression in benign and malignant skin tumours. Br. J. Dermatol. 128, 237-241, 1993.

Seiji M., and Mizuno F.: Electron microscopic study of Bowen's disease. Arch. Dermatol. 99, 3-16, 1969.

Sober A.J., and Burstein J.M.: Precursors to skin cancer. Cancer 75, 645-650, 1995.

Suzuki T., Ueda M., Ogata K., Horikoshi T., Munakata N., and Ichihashi M.: Doses of solar ultraviolet radiation correlate with skin cancer rates in Japan. Kobe J. Med. Sci. 42, 375-388, 1996.

Tada H., Hatoko M., Tanaka A., Kuwahara M., and Muramatsu T.: Expression of desmoglein I and plakoglobin in skin carcinomas. J. Cutan. Pathol. 27, 24-29, 2000. 
Takata M., and Matsui Y.: Proliferating cell nuclear antigen (PCNA) and p53 protein expression in Bowen's disease. J. Dermatol. 21, 947-952, 1994.

Thestrup-Pedersen K., Ravnborg L., and Reymann F.: Morbus Bowen. A description of the disease in 617 patients. Acta. Derm. Venereol. 68, 236-239, 1988.

Tsuji T., Shrestha P., Yamada K., Takagi H., Shinozaki F., Sasaki K., Maeda K., and Mori M.: Proliferating cell nuclear antigen in malignant and pre-malignant lesions of epithelial origin in the oral cavity and the skin: an immunohistochemical study. Virchows Arch. A. Pathol. Anat. Histopathol. 420, 377-383, 1992.
Yeh S., How S.W., and Lin C.S.: Arsenical cancer of skin. Histologic study with special reference to Bowen's disease. Cancer 21, 312-339, 1968.

Yu C.C., Fletcher C.D., Newman P.L., Goodlad J.R., Burton J.C., and Levison D.A.: A comparison of proliferating cell nuclear antigen (PCNA) immunostaining, nucleolar organizer region (AgNOR) staining, and histological grading in gastrointestinal stromal tumours. J. Pathol. 166, 147-152, 1992.

Ziegler A., Jonason A.S., Leffell D.J., Simon J.A., Sharma H.W., Kimmelman J., Remington L., Jacks T., and Brash D.E.: Sunburn and p53 in the onset of skin cancer. Nature 372, 773-776, 1994. 